\title{
[ The American Dreams and Nightmares of Polish Immigrants ]
}

\section{Agnieszka Trąbska}

Jan Dlugosz University, Czestochowa, Poland

[Abstract] This article focuses on the theme of the American Dream and its dark side in relation to Polish immigration to America. It attempts to explain various reasons behind Polish immigration based on the immigrants' age and social status, as well as the unpleasant consequences of their decision to leave their homeland. The issues faced by Polish immigrants and Polish Americans can be better understood in the light of a brief outline of the sociopolitical situation in Poland. The aim of this article is to demonstrate the negative effects of immigrants' belief in the American Dream and to shed light on the intergenerational identity of Polish Americans.

[Keywords] Polish immigrants, Polish Americans, the American Dream 
According to information provided by John G. Keane, Poland contributes the eighth largest percentage of the foreign-born population in the United States (qtd. in Aroian 75). This figure is mainly due to three major waves of immigration that took place from the late nineteenth and the twentieth century (Mello 183). Accumulated fears and anxieties caused by the upcoming war, followed by the ravages of war and sudden political changes, resulted in a sense of collective insecurity. Therefore many Poles followed the popular trend and chose to go west in order to find peace and escape poverty. As recorded by Mary Patrice Erdmans, the most recent cohort emigrated from communist Poland for both economic and political reasons. Some, discouraged by the failing economy, came to America seeking financial gain (Erdmans 179). Nevertheless, an improved financial situation was not their only motivation toleave the country. Others, especially refugees who had been involved in the Solidarność ("Solidarity") ${ }^{1}$ movement, desired to escape political repression.

In America, these refugees remained actively involved in the political and social changes in Poland in the 1980s, which shows that they had a strong commitment to their national identity (Erdmans 179). During this period, Polish immigrants, along with many other ethnic minorities, transferred their customs, traditions, and habits as part of their adaptation to the new reality and developed their own sense of national identity, trying to fill humanity's profound need to belong. However, Scaachi Koul, an Indo-Canadian author, claims that "fitting in is a luxury rarely given to immigrants, or children of immigrants. We are stuck in emotional purgatory. Home, somehow, is always the last place you left, and never the place you are in" (Koul 90). The difficulties associated with immigration that Polish Americans had to face found an outlet in literature. Although Polish immigrants and Americans of Polish descent constituted several significant communities, Polish American fiction originally did not gain major recognition. This changed in the late twentieth century, when the contribution of ethnic groups became acknowledged as meaningful to the overall development of American literature.

This paper will focus on three works that consider Polish immigrant identity; however, their authors represent different eras. It seems fitting to begin with Henryk Sienkiewicz, a Polish writer who to this day is considered "one of the greatest and most influential writers in Polish history” (Bielecki). Henryk Sienkiewicz (1846-1916), a Nobel Prize laureate, ${ }^{2}$ enriched world literature of the nineteenth and twentieth century. When pursuing his career in journalism, Sienkiewicz travelled to America and wrote several articles as well as works of fiction concerning the situation of American Polonia. Sienkiewicz's Za Chlebem (1880) reveals contradictions between the idea of the American Dream and the actual experience of being an immigrant. Another author who deals with the theme of immigration is Stuart Dybek (born 1942). In his Childhood and Other Neighborhoods (1980) he touches upon the issue of immigration when exploring the intergenerational identity of Polish Americans. Karolina Waclawiak (born 1979) provides a more recent view on the same theme; however, in her novel How to Get Into the Twin Palms (2012) she focuses on a profound need to belong. This paper will attempt to shed light on the causes and consequences of leaving a homeland in search of prosperity, peace, or a better future, taking into account disparities between the generations of immigrants. 
In their works concerning immigration to the United States, writers of Polish origin cover issues that are vital to understanding the alienation and nostalgia of immigrants, such as national identity, prejudice, isolation, and both sides of the American Dream. The latter item in this list, an idealistic concept, has been broadly explored in works of literature concerning foreigners and their motivations for emigrating to America. An American writer and historian, James Truslow Adams, has stated that the American Dream is the dream of a land in which life should be better and richer and fuller for every man, with opportunity for each according to their ability or achievements (Adams 404). He further explains that:

It is a difficult dream for the European upper classes to interpret adequately, and too many of us ourselves have grown weary and mistrustful of it. It is not a dream of motor cars and high wages merely, but a dream of social order in which each man and each woman shall be able to attain to the fullest stature of which they are innately capable, and be recognized by others for what they are, regardless of the fortuitous circumstances of birth or position. (Adams 404)

Adams admits that although material wealth has been an important consideration, the American Dream is a dream of being able to grow to the fullest development as men and women (Adams 405). He indicates that the American Dream was not an economic migration:

The American Dream was beginning to take form in the hearts of men. The economic motive was unquestionably powerful, often dominant, in the minds of those who took part in the great migration, but mixed with this was also frequently present the hope of a better and freer life, a life in which a man might think as he would and develop as he willed. The migration was not like so many earlier ones in history, led by warrior lords with followers dependent on them, but was one in which the common man as well as the leader was hoping for greater freedom and happiness for himself and his children. (Adams 31)

Apart from Adams' definition, the American Dream has become surrounded by the myth of prosperity with the passage of time. This vision of wealth and opportunity to progress encouraged many Poles to abandon their homeland and follow their own American Dream, regardless of the consequences. But as some authors of Polish descent suggest, achieving the American Dream is nearly impossible without achieving a sense of belonging to a place as well as to a community.

Henryk Sienkiewicz spent a couple of years in America in the late nineteenth century and used this time to observe his Polish compatriots - and the process of cultural assimilation they were undergoing. His expedition proved to be very inspirational, resulting in several literary works concerning Polish Americans, immigrants, and their own perception of America. As a journalist, Sienkiewicz travelled to America before it became a popular destination for Poles; therefore his literary works concerning various elements of Polishness in America include the yet unnamed theme of the American Dream. 
In his novella $Z a_{\text {chlebem }}^{3}$ (For Bread), Sienkiewicz portrays the story of a Polish family who see their only hope in economic emigration to their own Promised Land - America. Blinded by empty promises and the common misconception of America, the head of the family, Lorenz Toporek, decides to leave his belongings and start a new life in a foreign land. The reality completely contradicts his initial expectations; both Lorenz and his daughter, Mary, do not know much about the New World. They are also unfamiliar with the language, so they struggle to adjust to their new circumstances. As poor and helpless immigrants, they encounter nothing but contempt and insults from the local population, and they are deprived of fundamental social rights. "Help they get from none," Sienkiewicz writes, "Many Poles live in New York, but the well-to-do never live in the vicinity of Chatham Square" (Sienkiewicz 64). Local people form their own closed community and prefer not to let any foreigners in, but instead give them very disapproving looks full of suspicion. "Old Lorenz had tried to get work, but no one understood what he wanted... besides, an Irishman had given him a black eye" (Sienkiewicz 59). Due to numerous tragic plot twists, the Polish immigrants lose everything they have managed to gain with the help of a good old gentleman in New York. After rescuing them from their misery, he gives them his card and says that if they ever get into trouble, they should come to him and he will take care of them (Sienkiewicz 132-133). Actually, within the context of estrangement, the appearance of the generous stranger moved by their plight is crucial, for due to his actions the family receives selfless help for the very first time. Having overcome many problems, loneliness, and humiliation, the immigrants find comfort in him and then finally seem to cope with their unfavorable situation. Left on their own, they become invisible, and are once again ignored by the other inhabitants. Poor immigrants die in obscurity, forgotten by everyone. "In this great city, that hummed like a mighty engine, everybody rushed onward and looked only ahead, so that they could not see the suffering of others" (Sienkiewicz 61).

This story illustrates the importance of a sense of belonging and acceptance. Contrary to the popular myth of American prosperity, Za chlebem represents the dark side of the American Dream and the unintended negative effects that it brings to Polish American society. However, it is also worth reflecting on the meaningful title of this novella; Sienkiewicz uses a phrase that highlights the misery and despair of the immigrants. Due to its sacral character, bread is considered an essential symbol of life. Accordingly, Sienkiewicz emphasizes that the immigrants do not seek delicacies or luxury, as they are not motivated by greed; they were forced to leave their homeland in search of bread.

After the first-wave immigrants settled permanently and started their families, they gave birth to the second generation of Polish Americans. Since the immigrants' children were born and raised in America, they faced the clash of two cultures and attitudes, American and Polish. Mary Patrice Erdmans clarifies that ethnic identity emerges from the initial interaction between the immigrants' homeland culture and American society, and later interactions between the ethnic subculture and the dominant society (Erdmans 177). She also implies a distinction between immigrants and ethnics, which is expressed in each group's languages, religious rituals, and political beliefs (Erdmans 179). Over the 
decades, members of Polish American communities have changed - because in many respects, Poland itself has changed. Polish immigrants and Polish Americans have experienced various manifestations of Poland in terms of the country's history, culture, and degree of urbanization. According to Erdmans, the post-WWII cohort and the most recent immigrant cohort are better educated and more urbanized than the earlier cohort. ${ }^{4}$ Hence, they identify with the intellectual components of an evolving Polish nation and culture (Erdmans 180). These observations support the thesis that differences in class and social status affect the understanding and perception of Polishness. New immigrants describe it as "not having anything in common" with the "early peasants" - mostly "uneducated laborers" who "signed their name with an X" (Erdmans 180). Considering the disparities between ethnics and immigrants, but also between particular cohorts of immigrants, it seems that the aspirations as well as the expectations of Polish Americans and Polish immigrants have evolved over time. The aim of surviving, previously associated with American Polonia, was replaced with the aim of achieving, especially after "Poland gained international prominence in the 1980s (as a result of the pontification of Karol Wojtyła as Jan Pawel II, the rise of Solidarność, and the fame of Lech Wałęsa), it became more socially interesting to be Polish" (Erdmans 182).

Stuart Dybek, an American writer of Polish descent, combines various elements of Polishness with an American setting in his literary works. Dybek was born and raised in an immigrant neighborhood called Pilsen ${ }^{5}$ in the southwest of Chicago ${ }^{6}$, therefore for him ethnicity is itself a natural and integral part of the human condition. Additionally, Dybek is among the first writers of Polish descent (who write about the ethnic self) to receive national recognition. Thomas Gladsky indicates the impact that Chicago, with its ethnic neighborhoods, has on Dybek's characters (Gladsky 106-108). Between the late 1800s and early 1900s, there was an influx of Polish, Czechs, Slovaks, and Lithuanians to the Pilsen neighborhood. Beginning in the 1950s, the Latino population expanded; however, by the 1960s only the Polish population outnumbered Latinos in Pilsen (Betancur 6), a fact that strongly affected Dybek's literary work.

In his collection of short stories Childhood and Other Neighborhoods, Dybek addresses the theme of coming-of-age. His characcters' transition from childhood to adulthood appears to be particularly challenging, as the protagonists are influenced by highly diversified communities. Dybek's characters in this collection are generally young people, often second- or third-generation Poles making their homes in Chicago (May 364). In his stories, Dybek vividly illustrates inter-generational differences among Polish Americans by introducing characters of various age groups. The elderly characters appearing in "Blood Soup" and "Neighborhood Drunk" play an integral role, especially in respect to national traditions and cultural heritage. Furthermore, they serve as a reliable source of information on what Polishness actually is. Dybek also emphasizes their commitment to Poland by frequent use of Polish words and phrases, often adapted to American pronunciation, such as busha (grandmother) or dzia dzia (grandfather).

In "Neighborhood Drunk", the fourth of eleven stories, Dybek introduces a multigenerational family that consists of children, parents, and grandparents. Danny, who 
represents the young generation, plays the role of an observer and a witness of the challenges that adjustment brings. His grandfather reveals the underlying motivation behind the family's emigration, which seems to be distant from today's understanding of the American Dream. "Danny's dzia dzia, always told the same story in broken English about how he came to America because he didn't want to be in the czar's army” (Dybek 54). Dybek, similarly to Sienkiewicz in Za Chlebem, emphasizes that the first-wave immigrants were not primarily seeking a chance to increase their wealth, but rather to make ends meet and find a sense of security. In both "Neighborhood Drunk" and "Blood Soup," the grandparents' stories occasionally seem to be neglected by their ethnic grandchildren, as they are not completely familiar with the issues of being a foreigner in a strange land. In "Blood Soup", a young man named Steve, also known as Stefush, realizes that his grandmother may be dying, and to bring her relief he faces the challenge of finding some duck blood to prepare czarnina, a traditional Polish soup, which is "a strong smelling mixture of carrots, apples, prunes, flour, sour cream, parsley, thyme, and duck's blood” (Dybek 26). Busha treats it as a very effective cure; she encourages Stefush to taste the soup for she believes it will make him stronger. Moreover, his grandfather loved it (Dybek 27). However, when his uncles see the soup simmering on the stove they began laughing and joking that it is "time for the family's oral transfusion" (Dybek 27). This reveals the disparities between generations of Polish Americans.

According to John A. Merchant, Dybek's protagonists are third-generation Polish Americans who look upon their Polishness as either something strange or mystifying (Merchant 502). Merchant also refers to Gladsky's suggestion that they see older Polish people as the 'other,' and to Gladsky's opinion that "the more Polish the character, the more bizarre are Dybek's stories" (qtd. in Merchant 502). Despite the bizarreness of the Polish characters, with the character of the grandmother who appears in "Blood Soup" Dybek also illustrates traditional Polish hospitality and loving kindness, which is described as "a kind of love that must have come from the Old Country-instinctive, unquestioning-like her strength, something foreign that he couldn't find in himself, that hadn't even been transmitted to his mother or any of Busha's other children" (Dybek 26). Busha tries to instill Polishness in her descendants, along with a respect for tradition and religious devotion. Her grandson, Stefush, remembers how "Busha would give him a dime" if he kissed the holy pictures of Jesus and Mary. He also remembers "the taste of dusty glass on his lips" (Dybek 26). When Stefush looks at his poor and sick grandmother, he wishes he believed in the holy images' power strongly enough now to pray for her (Dybek 26). As is observed by Merchant, these religious references also reveal what has been lost to the younger generation. Dybek's protagonists engage in the rituals out of habit; they do not fully comprehend the silent spirituality of the older generation (Merchant 503).

Although the characters introduced in Childhood and Other Neighborhoods represent a single community, they have different attitudes regarding their lives in America and their own perception of the American Dream. Merchant claims that "a unifying element among nearly all Dybek's characters is a sense of loss or disconnection from their clumsily concealed ethnic identities [...] the middle stage of explanation and understanding 
between generations is missing" (Merchant 501). The representatives of the first generation of immigrants introduced in this book could not feel safe in Poland, mainly due to political reasons; Danny's grandfather, a character in "Neighborhood Drunk", knew that if he had stayed in Poland, he would have been forced to join the Russian army (Dybek 54). Despite living in a foreign land, he still retains his old habits such as using Polish words and drinking in the street (Dybek 54). All this probably helps him to overcome the difficulties caused by being a foreigner in his poor immigrant district of Chicago. Similarly, in "Blood Soup," Grandmother's behavior leads to the assumption that her American Dream is likewise to remain Polish and to plant the notion of Polishness in the hearts and minds of her descendants, in order to hold her family together.

To depict the image of Polish American culture, Dybek does not embellish the daily reality. Although he tries to depict both positive and negative aspects of Polishness, he seems to be focused mainly on the unfavorable attributes, disgusting habits, and everyday problems and obstacles, at the same time exaggerating the 'otherness' of Polish Americans. Such a depiction gives the impression that they are ugly uneducated peasants who seem to be far from fitting into the idea of the American Dream.

A more recent view of the American Dreams of Polish immigrants is provided by Karolina Waclawiak, the author of the novel How to Get Into the Twin Palms. Anya, the protagonist and narrator, is not satisfied with her Polish roots; she has long attempted to inhabit her Polish skin but now she is happy to "finally crawl out of it" (Waclawiak 5). Anya admits that she "never wanted to be a good Polish girl" (Waclawiak 20), yet she tries to explore her identity and to belong somewhere. Although she takes classes on assimilation where she can "learn to be American" (Waclawiak 20), she feels somewhat torn between two cultures - but also between the immigrant waves. "The second wave of immigrants from Poland, Russia, Laos, Cambodia. We couldn't speak to one another. They were too fresh" (Waclawiak 21), she says. She "wasn't off the boat anymore, like these people" (Waclawiak 21). Despite her efforts to behave and look like a "slim and tan and newly American" girl (Waclawiak 22), she hears from her father that she looks like "an escapee from a concentration camp" (Waclawiak 22). Nor are her efforts appreciated by the American camp counselors, who look down on her. Nevertheless, Anya remains hopeful that she "still had a chance in this country" (Waclawiak 22) and practices her mimicry, movements, and vocabulary to be more American (Waclawiak 22).

Living in a Russian neighborhood of Los Angeles, Anya frequently observes the nearby Twin Palms nightclub, "the pinnacle of exclusivity in the Russian community" (Waclawiak 2). Amazed by the place, she is desperate to belong there, just like the Russians do - since, in fact, she seems to be neither Polish nor American. After a desired change in her appearance, Anya arouses the interest of Russian men; she imagines people asking what her nationality is, "Polska? Ruska? Svedka? Or maybe just Amerykanska," but they "couldn't tell” (Waclawiak 8). She cherishes this moment of being approved of as a prospective member of their closed community.

To explain the very complex issue of a young immigrant's identity, Waclawiak refers to Gary Shteyngart’s definition of "1.5 Generation" (Gay). "1.5 Generation" is a term used 
to describe people who arrived in the United States as children and adolescents (Berestein Rojas). Leslie Berestein Rojas provides further explanation of the possible roles that child immigrants can play within immigrant diasporas: "Depending on how old 1.5s are upon arrival, where they grow up, which ethnic group they belong to and a host of other factors, their American/immigrant identities vary wildly, as do the roles they play within immigrant diasporas. They can play bridge-builder and cultural interpreter, helping parents and grandparents navigate their new home. Or they can feel like outcasts, neither here nor there" (Berestein Rojas). Unlike their first-generation parents, their identity is split (Berestein Rojas), and so is Anya's.

Indeed, the feeling of "being from nowhere" never leaves Anya. She lacks any form of permanence (Waclawiak 11). Her desperate need to belong leads to harmful addictions (Waclawiak 38), an intimate relationship with a repulsive man (Waclawiak 62-63), and an abandonment of what remains of her Polishness. Anya even decides to change her Polish name, Zosia, to be less Polish (Waclawiak 18). During a call with her mother, Anya declares that she is living the American Dream (Waclawiak 127); however, she has paid a high price for this superficial illusion of satisfaction, and she is soon to realize that she needs both spiritual and physical purification. For this purpose, she goes to the shower and scours her skin, taking off layer after layer (Waclawiak 184). Apart from the complex depiction of the protagonist's 1.5 generation ethnic identity and its impact on her life choices, Waclawiak illustrates an interesting contrast between Anya and her parents. For adult immigrants, their cultural integrity is already shaped, whereas Anya endeavors to explore her own identity and sense of belonging. In comparison to Anya, her parents appear to be less affected by the local culture; they therefore reveal characteristics that are typical of Poles, such as a clear negative attitude toward Russians (Waclawiak 5), profound religiosity, and a traditional conservative attitude (Waclawiak 128-129). Consequently, these differences in viewpoints create an intergenerational communication barrier. Anya never tells her mother about her decisions, admitting that "she hated lying to her and was bad at it" (Waclawiak 127).

In How to Get Into the Twin Palms, Waclawiak presents an upsetting image of a young woman's self-deprecation in the pursuit of what she sees as her own American Dream. Despite making many sacrifices, and despite her strong motivation to reach her goal and find her own place in the world, she experiences the dark side of the American Dream firsthand. Eventually, she has nothing but loneliness, which is so "alive and present in Anya's world that it really becomes a tangible thing rather than just an abstract feeling" (Gay).

Despite the original definition of the American Dream, its general perception has changed over time. In his definition of the national ethos of the United States, Adams includes the idealistic concepts of freedom, equality, and self-development. Moreover, he indicates its accessibility. The American Dream allows each man and each woman to attain the fullest stature of which they are innately capable regardless of birth or position (Adams 404). However, many of the immigrants seem to be deprived of this chance. As Adams admits, "the immigrant who came to America was greatly looked down upon, 
because of his strangeness, frequent uncouthness, and low standard of living" (Adams 180). The immigrants are put in an inferior position, for they often "took the low-paid manual jobs working for other men, which the American had declined not on the score of their being manual but because of their being for others" (Adams 180). The characters described in this article live with this stigma of being 'the other' and therefore their desperate pursuit of their own American Dream seems to be extremely challenging, as depicted in Dybek's Childhood and Other Neighborhoods, or even self-destructive, as in Sienkiewicz's Za chlebem or Waclawiak's How to Get Into the Twin Palms. The American Dreams of Polish immigrants take various forms, depending on the individual's needs, from the fundamental need for security to a desire for professional fulfillment. Regardless of whether their American Dream is to find financial stability, a sense of security, or a place to belong, eventually the American Dream may appear to be the American Nightmare.

\section{[Notes]}

1 Solidarność refers to both a movement and an organization founded in August 1980. It was one of the largest social movements in history: "Because of its size and popularity, it threatened the very foundations of communist rule in Poland" (Mason 41).

2 In 1905, Sienkiewicz was awarded the Nobel Prize for Literature because of his "outstanding merits as an epic writer" (Napierkowski 47).

3 Za chlebem also refers to the early cohort of immigrants due to their low level of education.

4 Mary Patrice Erdmans distinguishes three Polish immigrant cohorts and depicts the differences between them with regard to Poland's political situation, their main motives for emigrating, the cohort's educational level, and the size of the cohort. According to data provided by Erdmans, the Early Cohort (1870-1913), which emigrated from partitioned Poland mainly for economic reasons, was the largest of the three cohorts. Nevertheless, it represented the lowest educational level, as many of the early immigrants were illiterate. The War Cohort's emigration (1939-1959) was primarily caused by political repression. It is estimated to be the smallest group (190,000 in comparison to 1,500,000 in the Early Cohort and 350,000 in the New Cohort), with a high educational level. The New Cohort emigrated from communist Poland for both economic and political reasons, and boasted a high level of education (Erdmans 179-180).

5 Pilsen's name was derived from Plzeň, a city in the Czech Republic.

6 Chicago has long been a destination for Polish immigrants. Therefore, the city often proclaims itself to be Poland's second city, with only Warsaw containing a larger Polish population (Pacyga 1). 


\section{[Bibliography]}

Adams, James Truslow. The Epic of America. Boston: Little, Brown, and Company, 1931. Aroian, Karen J. "Polish Immigrants in the U.S.: Adjusting to Capitalism." Polish American Studies 47.2 (1990): 75-86. JSTOR, www.jstor.org/stable/20148334. Accessed 20 May 2021.

Berestein Rojas, Leslie. "Gen 1.5: Where an Immigrant Generation Fits In.” Southern California Public Radio, 21 Mar. 2012, www.scpr.org/blogs/multiamerican/2012/03/21/7963/ what-is-a-1-5-where-an-immigrant-generation-fits-i/. Accessed 18 May 2021.

Betancur, John. "Gentrification Before Gentrification? The Plight of Pilsen in Chicago.” Nathalie P. Voorhees Center for Neighborhood and Community Improvement. Chicago: University of Illinois, 2005.

Bielecki, Maciej. "Henryk Sienkiewicz: A Writer to Comfort Polish Hearts.” Great Poles, https://www.greatpoles.pl/index.php/historical-poles/69-henryk-sienkiewicz. Accessed 30 August 2021.

Dybek, Stuart. Childhood and Other Neighborhoods. Chicago: University of Chicago Press, 1980.

Erdmans, Mary Patrice. "Immigrants and Ethnics: Conflict and Identity in Chicago Polonia.” The Sociological Quarterly 36.1 (1995): 175-195.

Gay, Roxane. “The Rumpus Interview with Karolina Waclawiak.” The Rumpus, 2 Jul. 2012. therumpus.net/2012/07/the-rumpus-interview-with-karolina-waclawiak/. Accessed 18 May 2021.

Gladsky, Thomas S. "From Ethnicity to Multiculturalism: The Fiction of Stuart Dybek." MELUS: Multi-Ethnic Literature of the U.S. 20.2 (1995): 105-118.

Koul, Scaachi. "Aus-piss-ee-ous.” One Day We'll All Be Dead and None of This Will Matter: Essays. New York: Picador, 2017. 77-110.

Mason, David S. “Solidarity as a New Social Movement.” Political Science Quarterly 104. 1 (1989): 41-58. JSTOR, www.jstor.org/stable/2150987. Accessed 25 May 2021.

Mello, Caitlin. "Polish Immigration to Chicago and the Impact on Local Society and Culture.” Language, Culture, Politics. International Journal 1. 1 (2020): 183-193.

Merchant, John. "Recent Polish-American Fiction," The Sarmatian Review 18. 1 (January 1998): 501-508.

May, Charles Edward, ed. “Stuart Dybek.” Short Story Writers, vol. 1. Pasadena, CA: Salem Press, 2008. 364-367.

Napierkowski, Thomas. "Sienkiewicz in America: 1876 and 1991." Polish American Studies, 49.1 (1992): 45-55. JSTOR, www.jstor.org/stable/20148373. Accessed 24 May 2021.

Pacyga, Dominic A. American Warsaw: The Rise, Fall, and Rebirth of Polish Chicago. Chicago; London: University of Chicago Press, 2019.

Sienkiewicz, Henryk. After Bread: A Story of Polish Emigrant Life to America. New York:

R. F. Fenno \& Company, 1897.

Waclawiak, Karolina. How to Get Into the Twin Palms. Two Dollar Radio, 2012. 


\section{[Address]}

Jan Dlugosz University in Czestochowa

Faculty of Humanities

Aleja Armii Krajowej 36 A

42-200 Czestochowa

Poland

a-trabska@wp.pl

Agnieszka Trąbska received her Bachelor's degree in English Philology

from Jan Dlugosz University in Czestochowa. She is currently studying for a Master's degree. Her interests include American children's literature and Polish migrant literature. 